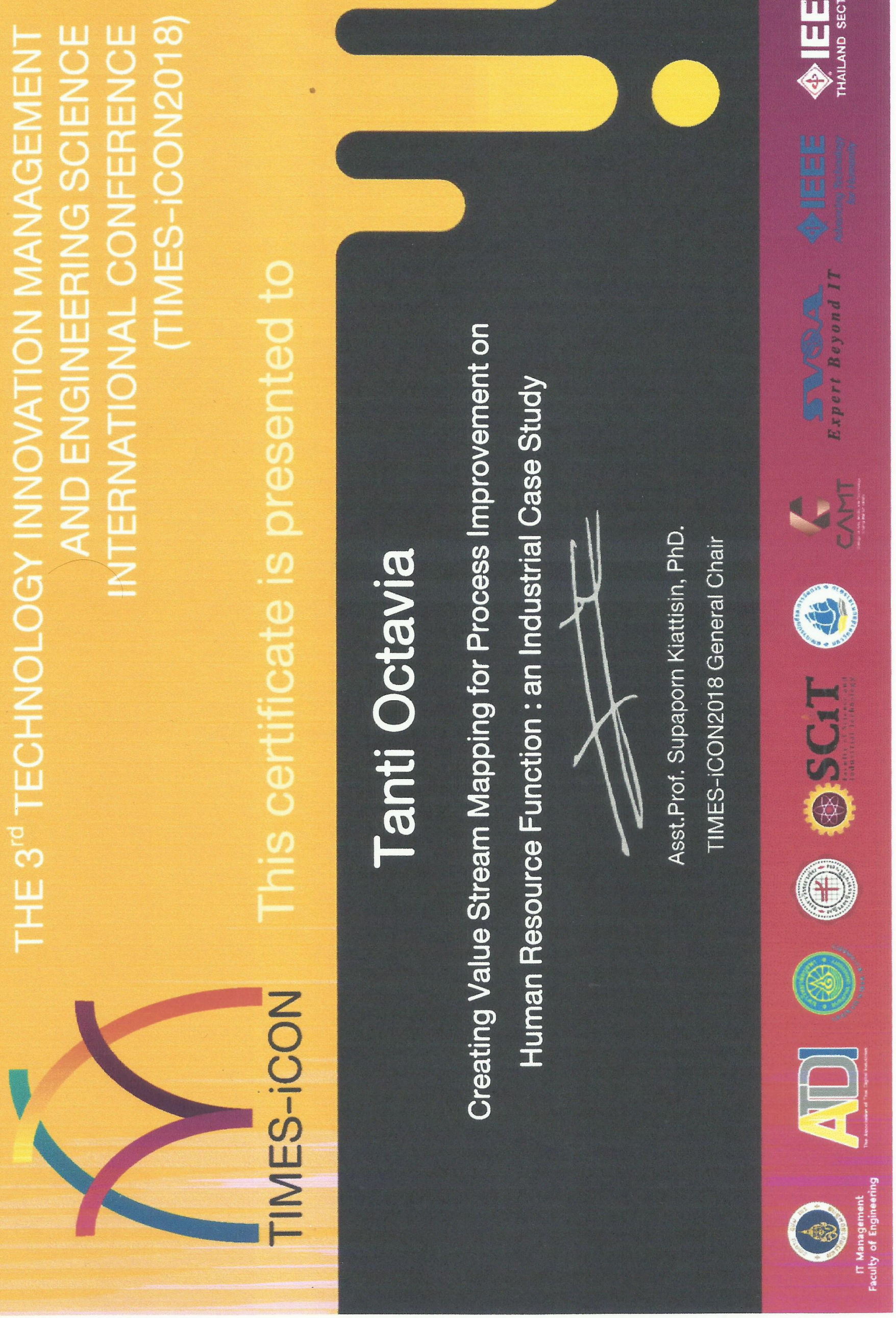




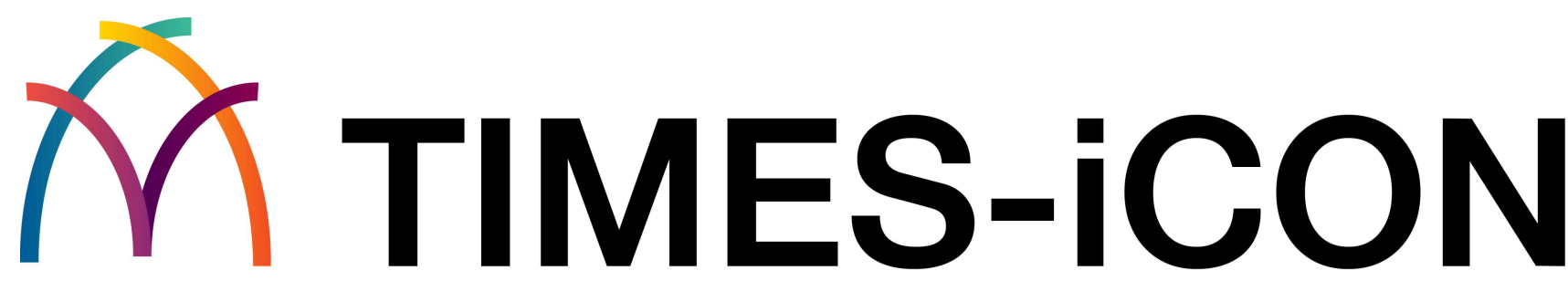

(http://times-icon.org/2018/)

Home

(http://times-icon.org/2018/)

Call for Papers

(CFP-TIMES-iCON2018.pdf)

Organizing Committee

(committee.html)

International Steering Committee

(International_Committee.html)

Important Dates

(important_date.html)

Conference Program new

(conf_program.html)

Keynote Speakers new

(keynote_speaker.html)

CameraReady

(cameraready.html)

Paper Submission

(PaperSubmission.html)

Registration

(registration.html)

Venue

(venue.html)

Past Conference (TIMES-iCON2017)

(http://times-icon.org/2017)

Past Conference (TIMES-iCON2016)

(http://times-icon.org/2016)

About us \& Contact us 


\section{TIMES-iCON2018}

December 12-14, 2018 Bangkok, Thailand

\section{Organizing Committee}

\section{Honorary Chair}

- Jackrit Suthakorn, Mahidol University

\section{General Chair}

- Supaporn Kiattisin, Mahidol University

\section{Technical Program Chair}

- Sotarat Thammaboosadee, Mahidol University

- Smitti Darakorn na Ayutthaya, Mahidol University

- Bunlur Emaruchi, Mahidol University

- Manutsiri Chansutthirangkool, Mahidol University

\section{Publicity Chair}

- Prush Sa-nga-ngam, Mahidol University

- Wasin Srisawas, Mahidol University

\section{Publication Chair}

- Adisorn Leelasantitham, Mahidol University

- Yutthapong Aunhataweesup, Mahidol University

- Jarurote Tippayachai, Mahidol University

\section{Local Arrangement Chair}

- Taweesak Samanchuen, Mahidol University

- Theera Piroonratana, Mahidol University

\section{Finance Chair}

- Chanattha Chansutthirangkool, Mahidol University

- Luksamee Chujai, Mahidol University

- Suchanya Ratsadonniyom, Mahidol University 
Steering Committee

- Adisorn Leelasantitham, Mahidol University

- Apichat Terapasirdsin, Rajamangala University of Technology Isan

- Apinan Aurasopon, Mahasarakham University

- Atichart Harncharnchai, Chiang Mai University

- Itthiphol Eampoonga, Mahasarakham University

- Kairoek Choeychuen, Rajamangala University Of Technology Rattanakosin

- Laor Boongasame, Bangkok University

- Manirath Wongsim, Mahasarakham University

- Nanti Suthikarnnarunai, University of the Thai Chamber of Commerce

- Nattasit Gerdsri, Mahidol University

- Orapadee Joochim, King Mongkut's University of Technology Thonburi

- Ornnapa Tasnaina, Kasetsart University

- Prasong Praneetpolgrang, Sripatum University

- Punnarumol Temdee, Mae Fah Luang University

- Ratchada Kongkajan, Thammasat University

- Roungsan Chaisricharoen, Mae Fah Luang University

- Sarunya Lertputtarak, Burapha University

- Somkeit Noamna, Chiang Mai University

- Sotarat Thammaboosadee, Mahidol University

- Supasit Lertbuasin, Burapha University

- Suphakant Phimoltares, Chulalongkorn University

- Taweesak Samanchuen, Mahidol University

- Thanatchaphan Petcharat, Prince of Songkla University

- Thanwadee Chinda, Thammasat University

- Thawatchai Suwanapong, Prince of Songkla University

- Watcharachai Wiriyasuttiwong, Srinakharinwirot University

- Waranyu Wongseree, King Mongkut's University of Technology North Bangkok

- Werapon Chirachalit, King Mongkut's University of Technology Thonburi

- Wimol San-umm, Thai-Nichi Institute of Technology

- Yodying Thanatawee, Burapha University

\section{General Secretaries}

- Adisorn Leelasantitham, Mahidol University

- Rojjalak Chuckpaiwong, Mahidol University 


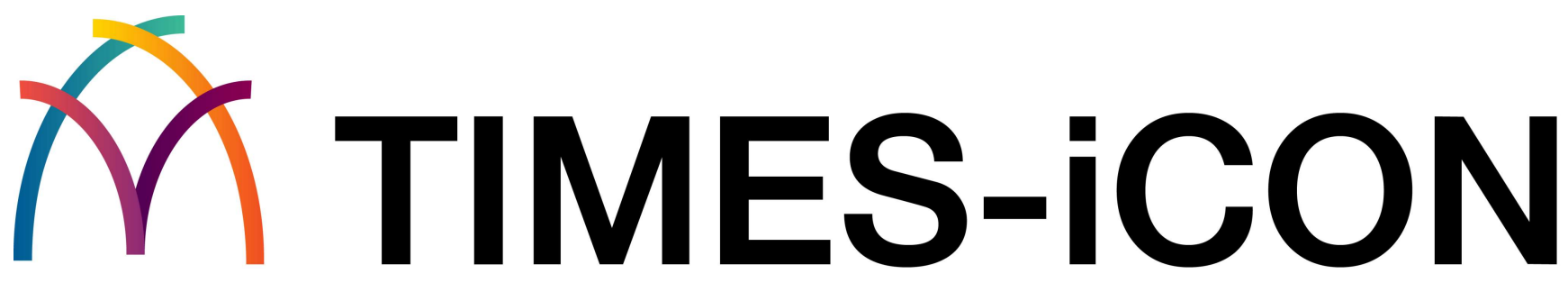

(http://times-icon.org/2018/)

\section{Home}

(http://times-icon.org/2018/)

Call for Papers

(CFP-TIMES-iCON2018.pdf)

Organizing Committee

(committee.html)

International Steering Committee

(International_Committee.html)

Important Dates

(important_date.html)

Conference Program new

(conf_program.html)

Keynote Speakers

(keynote_speaker.html)

CameraReady

(cameraready.html)

Paper Submission

(PaperSubmission.html)

Registration

(registration.html)

Venue

(venue.html)

Past Conference (TIMES-iCON2017)

(http://times-icon.org/2017)

Past Conference (TIMES-iCON2016)

(http://times-icon.org/2016)

About us \& Contact us

(aboutus_contactus.html) 


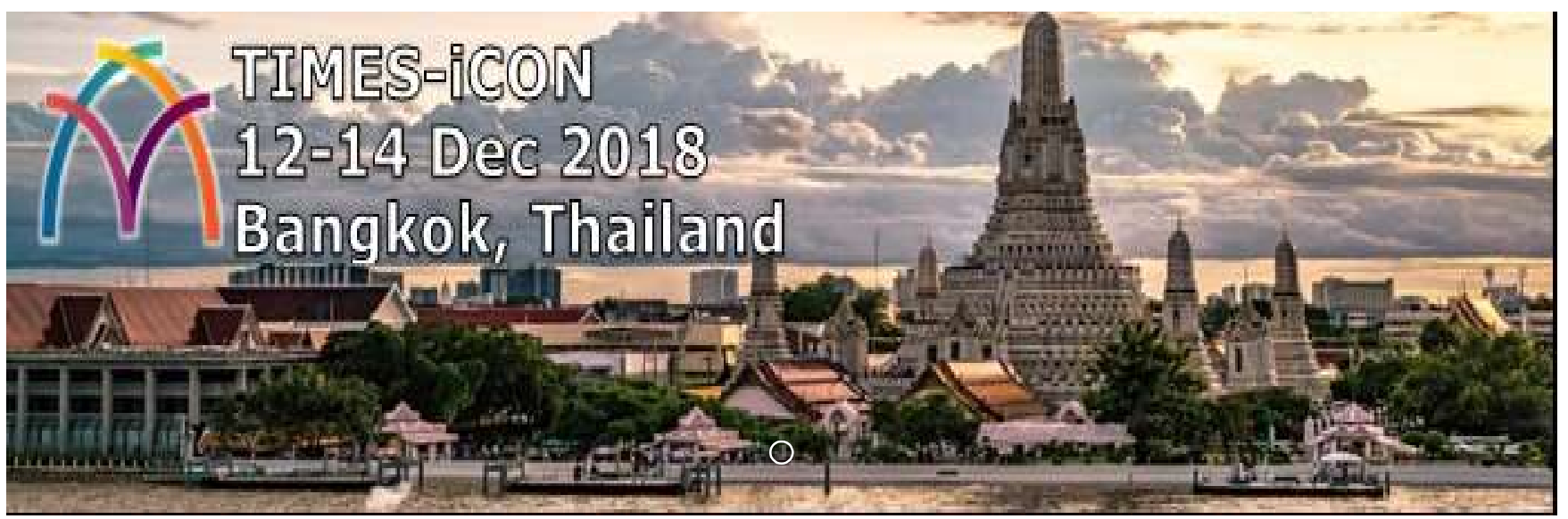

- Final program is ready. Please check it at Conference Program (conf_program.html) page.

- Authors who are unable to upload camera-ready via EDAS can send the paper in MsWord and PDF to secretary@times-icon.org.

- The review results of all submissions have been sent via email. Kindly check your email and status on the EDAS system. If you found any difficulties or did not receive the email, please contact secretary@times-icon.org.

- The registration detail is ready. Please see at registration page (registration.html). Noted that no handling fees for Paypal payment in USD, $5 \%$ handling fee for payment in BAHT)

The 3rd Technology Innovation Management and Engineering Science International Conference (TIMES-iCON2018) will be held in Bangkok, Thailand, December 12-14, 2018. The TIMES-iCON2018 will be the most comprehensive conference focused on management, innovation technology and information technology covering the research areas of the digital economy, digital society, digital healthcare, digital organization, digital country, digital government and digital transformation. All accepted papers are expected to be included in IEEE Xplore and indexed by El. Also selected papers are encouraged to extend and publish in ITMSOC journal or Journal of Global Business Review.

The TIMES-iCON2018 will be held in Bangkok, Thailand, on December 12-14, 2018. Bangkok is a capital city in Thailand. It is a center for tourists who will go and connect to other city. Bangkok is the city integrated between the part of old and new city which many interested places for the tourisms such as Wat Phra Kaew, The Grand Palace, Sanam Luang, Chao Phraya River, Khao San Road, Bangkok Chinatown Yaowarat, Chatuchak Market, Train Night Market Ratchada etc. The organizing committee is pleased to invite all researchers to attend the conference. The topics for regular sessions include, but are not limited to, the followings:

- Information Technology Management

- Data Science and Big Data

- Science and Technology Engineering

- Digital Business Management, Project Management and Organizational Development

- Digital Education, Innovation and Knowledge Management

- Strategic Management, Change Management and Entrepreneurship

- HR Management, Organizational Culture and Leadership in Digital Era

- Behavioral Sciences and Communication Studies

- Other related fields

- Thai Track

\section{Keynote Speaker}




\section{G and Digital Transformation}

Dr. Pheeradej Na Nan

Board Committee of Ph.D. Program, Information Technology Management (ITM), Faculty of Engineering, Mahidol University

Abstract: Nowadays, digital transformation reshapes our life and the customer journey in every industry. The fifth generation (5G) mobile network is about to accelerate this digital transformation.

Innovative digital services will require great demand from the next generation mobile network. To meet this demand, $5 G$ use cases are generally classified into three categories: enhanced mobile broadband (eMBB) supporting extremely-high resolution video that beyond the current connection speed; massive machine type communication (mMTC) which will be required in connecting low speed with massive number of the Internet of Things (loTs); and finally ultra-reliable low latency communication (URLLC) for efficient facilitation of latency-sensitive applications (such as autonomous vehicles, remote surgery, public safety and manufacturing robot).

$5 \mathrm{G}$ is able to bring forth a unique network that can deliver all these varied requirements. This necessity is changing network architecture and allows for cooperation with advanced network paradigms such as network slicing, controland-user plane separation, edge computing and virtualization of radio and core elements. With the introduction of a multitude of new complexities, many network elements that need to work together can do so with the aid of $5 \mathrm{G}$ technology.

Digital native enterprise is an organization that's capable of developing its operations and business innovation at a faster rate than a traditional enterprise is capable of. As the future of business landscape continues to change, it will be essential for organizations to transform into a digital native enterprise by using platform technologies and streamlining their business processes to become an excellent digital enterprise in this coming $5 \mathrm{G}$ era.

In this keynote session, we will have a discussion about opportunities and challenges for an enterprise to digitally transform their business through $5 \mathrm{G}$ technology. If an organization delays its digital transformation, the business opportunity might be lost.

Biography:Dr. Pheeradej Na Nan

- - Board Committee of Ph.D. Program, Information Technology Management (ITM), Faculty of Engineering, Mahidol University

- - Honorary Counsel, ClO World and Business Magazine

- - Contributing Editor, Strategy and Marketing Magazine

- - Invited Digital Technology Speaker in listed companies

- -Technology Columnist on Digital Technology and Strategy (more than 600 published articles)

PROFESSIONAL EXPERIENCE Selected Invited Talk and Columns on Digital Technology

- - Invites Speaker, "5G Strategy for Thailand," Chulalongkorn University, 2018

- - Invited Speaker, "Disruptive Technology: Al, loT, Big Data, Blockchain and 5G," National Engineering 2018

- - Invited Speaker, "Digital Transformation Strategy," Suthichai Live, 2018

- - Invited Speaker, "Trends in Wireless Intelligent Connectivity for Digital Society," The 5th International Workshop on Smart Wireless Communications (SmartCom 2018), The Institute of Electronics, Information and Communication Engineers (IEICE)

- - Invited Speaker, "5G and Digital Transformation," The Annual Seminar: IT Trends 2019, Dec. 2018

- - Invited Speaker, "Disruptive Technology: IoT, Big Data and Artificial Intelligence," National Engineering 2018, Nov. 2018.

- - Invited Speaker, "Digital Transformation for Private and Government Sectors," 2018

- - Invited Speaker, "Digital Transformation for Graduate students," 2018

\section{Paper Submission to EDAS system}


Prospective authors are invited to submit full-length papers, including figures, tables, and references, via our website at http://www.times-icon.org/2018/ (http://www.times-icon.org/2018/). All papers will be peer reviewed and handled electronically. All papers submitted must be previously unpublished and may not be considered for publication elsewhere at any time during the review period. Any accepted paper included in the final program is expected to have at least one author or qualified proxy attend and present the paper at the conference. For additional information and submission guidelines, please visit our website at http://www.times-icon.org/2018/ (http://www.times-icon.org/2018/).

\section{Important Dates}

All dates are on $\mathrm{GMT}+7$ time zone.

\begin{tabular}{|c|c|}
\hline Regular paper submission deadline & $\begin{array}{c}30 \text { September } 2018 \\
15 \text { Oetober } 2018 \\
31 \text { October } 2018\end{array}$ \\
\hline Notification of regular paper acceptance & 20 Oetober 2018 \\
\hline The notification letter will be sent to the authors as soon as possible. & 7 November 2018 \\
\hline Camera-ready submission deadline & 20 November 2018 \\
\hline Early registration deadline & 15 November 2018 \\
\hline
\end{tabular}

\section{Hosted by}

The Association of Thai Digital Industries

Technology of Information System Management Division

Faculty of Engineering, Mahidol University, Thailand

\section{Financial Sponsor}

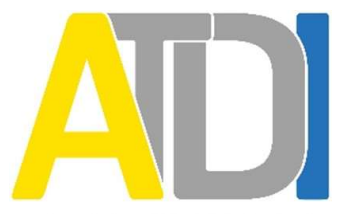

The Association of Thai Digital Industries

\section{Technical Sponsors}

\section{- IEEE \\ Advancing Technology for Humanity




\section{Patron}

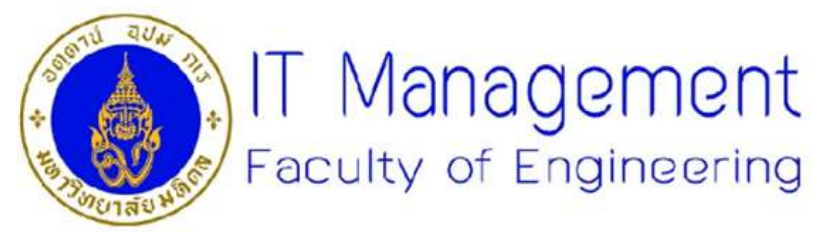

\section{Supporters}

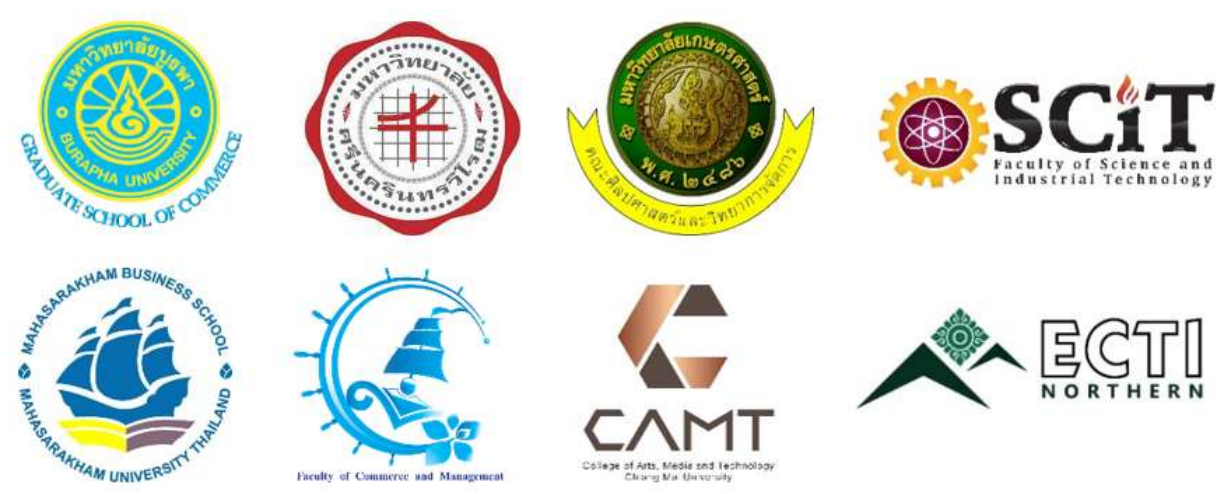




\section{Document details - Creating Value Stream Mapping for Process Improvement on Human Resource Function: An Industrial Case Study}

\author{
1 of 1 \\ $\rightarrow$ Export $\Perp$ Download More...>
}

TIMES-iCON 2018 - 3rd Technology Innovation Management and Engineering Science International Conference

22 January 2019, Article number 8621673

3rd Technology Innovation Management and Engineering Science International Conference, TIMES-iCON 2018; Bangkok; Thailand; 12 December 2018 through 14 December 2018; Category numberCFP18R77-ART; Code 144577

Creating Value Stream Mapping for Process Improvement on Human Resource Function: An Industrial Case Study(Conference Paper)(Open Access)

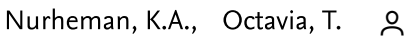

Industrial Engineering Department, Petra Christian University, Surabaya, Indonesia

Abstract

Continuous improvement is done on processes of human resource function at PT $\mathrm{X}$ which handles employees, the company's important assets using value stream mapping (VSM). There were four prioritized processes. Contact Centre was analyzed that medical status was inquired because of incomplete supporting documents so the list should be provided at medical claim application. Automatic tick for eligible family members for MBA can eliminate the questions. Talent review was improved with an integrated tool for 9-box, succession, movement, and data consolidation. Employee referral process was improved with consolidation of processes and weekly monitoring interview for backlog issue of hold candidates. Employee life cycle execution was improved with reducing number of validations and increasing number of system synchronization. Lead time efficiency obtained after mapping future state for employee contact centre, referral program, life cycle execution was $70 \%, 21 \%$ and $67 \%$. Process time efficiency obtained for talent review was 32\%. (c) 2018 IEEE.

SciVal Topic Prominence (i)

Topic: Lean Manufacturing | Value Stream Mapping | Kaizen

Prominence percentile: $99.541 \quad$ (i)

Author keywords

Continuous Improvement Human Resource Time Efficiency Value Stream Mapping Waste

Indexed keywords

Engineering Ef Efficiency Engineering research Life cycle Mapping Wastes

controlled terms:

Engineering

uncontrolled terms

Continuous improvements Human resource functions Industrial case study

Process Improvement Referral programs System synchronization Time efficiencies

Value stream mapping

Engineering main

heading:
Cited by 0 documents

Inform me when this document is cited in Scopus:

$\begin{array}{ll}\text { Set citation } & \text { Set citation } \\ \text { alert }> & \text { feed }>\end{array}$

Related documents

Find more related documents in Scopus based on:

Authors > Keywords >
ISBN: 978-153867573-1
DOI: 10.1109/TIMES-iCON.2018.8621673

Document Type: Conference Paper Sponsors: The Association of Thai Digital Industries (ATDI) 
○ Octavia, T.; Industrial Engineering Department, Petra Christian University, Surabaya, Indonesia;

(c) Copyright 2019 Elsevier B.V., All rights reserved.

$\begin{array}{lll}\text { About Scopus } & \text { Language } & \text { Customer Service } \\ \text { What is Scopus } & \text { 日本語に切り替える } & \text { Help } \\ \text { Content coverage } & \text { 切换到简体中文 } & \text { Contact us } \\ \text { Scopus blog } & \text { 切換到繁體中文 } & \\ \text { Scopus API } & \text { Русский язык } & \\ \text { Privacy matters } & \text { Pускй } & \end{array}$

\section{ELSEVIER Terms and conditions $\pi$ Privacy policy $\pi$}

Copyright @ Elsevier B.V त. All rights reserved. Scopus ${ }^{\circledR}$ is a registered trademark of Elsevier B.V.

We use cookies to help provide and enhance our service and tailor content. By continuing, you agree to the

Q RELX

use of cookies. 


\title{
Creating Value Stream Mapping for Process Improvement on Human Resource Function: an Industrial Case Study
}

\author{
Karina Angelica Nurheman, Tanti Octavia \\ Industrial Engineering Department \\ Petra Christian University \\ Surabaya, Indonesia \\ tanti@petra.ac.id
}

\begin{abstract}
Continuous improvement is done on processes of human resource function at $\mathrm{PT} X$ which handles employees, the company's important assets using value stream mapping (VSM). There were four prioritized processes. Contact Centre was analyzed that medical status was inquired because of incomplete supporting documents so the list should be provided at medical claim application. Automatic tick for eligible family members for MBA can eliminate the questions. Talent review was improved with an integrated tool for 9-box, succession, movement, and data consolidation. Employee referral process was improved with consolidation of processes and weekly monitoring interview for backlog issue of hold candidates. Employee life cycle execution was improved with reducing number of validations and increasing number of system synchronization. Lead time efficiency obtained after mapping future state for employee contact centre, referral program, life cycle execution was $70 \%$, $21 \%$ and $67 \%$. Process time efficiency obtained for talent review was $32 \%$.
\end{abstract}

IndexTerms-Continuous Improvement, Human Resource, Value Stream Mapping, Waste, Time Efficiency

\section{INTRODUCTION}

One of the leading manufacturers of consumer goods in Indonesia and also an affiliate of International Company aims to innovate and improve continuously to increase customer satisfaction. Continuous improvement at the company was not only done on production processes as the core business, but also on Human Resource (HR) function. This function has the task to find the right employee to be placed in an organization, develop and evaluate employees, and also provide welfare needs. The activities under the function are very important because they are closely related to human resources as the valuable assets of company. Based on the company's data in May 2016, HR must handle more than 30,346 employees spread across Indonesia.

The processes carried out by HR function at this company are very varied. There were four processes in HR that are prioritized to be improved. The four processes were employee contact center, talent review, employee referral program, and employee life cycle execution. Employee contact center is the process where HR handles each phone or email that occur every day. Talent review is a process where HR ensures that each individual employee has the right career path. The review process is conducted through three stages, namely: subfunctions, functions and company. Thus, it takes a long time. Referral program is a process where HR recruits prospective employees through referrals from employees of the company. The number of applicants is very high and should be given certainty rapidly by the HR. Employee life cycle execution is the process where HR change positions, salaries, location of employee. This process involves many stakeholders including an affiliate from abroad. Lean concept is used to improve on these four processes. One of the Lean tools used as a method to see problem is value stream mapping (VSM). VSM is expected to describe the whole process and identify waste or issues. The result of VSM can provide improvement ideas that can make process to become more efficient and lean.

\section{RESEARCH METHOD}

Lean is a business strategy that is based on the customer satisfaction by providing a quality product or service that suits needs in the right quantities and prices. Sayer and Williams [1] stated materials, equipment, manpower and time used should be at the minimum to achieve. The goal of lean is to build a culture of continuous improvement based on involvement and commitment of all the employees. Lean is also a management philosophy that provides improvement opportunities in terms of quality, cost and lead time. Moyano-Fuentes [2] mentioned the principles of Lean include customer value, value stream mapping, flow, pull, and perfection. Womak and Jones [3] defined the value stream as the set of all the "specific activities required to design, order, and provide a specific product, from concept to launch, order to delivery, and raw materials into the hands of the customer.

Value stream mapping (VSM) is one of lean tools for continuous improvement that describes the process for products and services. VSM helps to develop a common understanding of current process and highlights information for analysis. It defines vision of future process and serves as a goal for future lean activities. Therefore, the main purpose of VSM is to build same objective of every leaders and identifies possible areas for improvement and plans improvement activity. 
Value Stream Mapping attempts to identify and eliminate waste in the process. Activities considered waste is a timeconsuming activity, but does not add value to the resources of a product or service from the customer's perspective. Seven types of waste according to Lean can be shortened to TIMWOOD comprised of Transportation, Inventory, Motion, Waiting, Overproducing, Overprocessing and Defects. An example of waste in the office for transportation is moving document without changing it. An example of overprocessing waste is duplication of document [4].

In order to indicate the boundaries of VSM mapping, SIPOC charting should be applied. SIPOC stands for (S)upplier, (I)nput, (P)rocess, (O)utput, (C)ustomer. The first step in creating the SIPOC diagram is to make the process boxes. The second step is to determine the output and customer requesting the output. The third step is to determine the input and suppliers who supply these inputs. Supplier is the people, functions, and organizations supplying input [5].

VSM allows many improvement ideas to occur as waste or issues are identified. These improvement ideas need to be prioritized based on resources and time available ideas need to be prioritized based on resources and time available. Prioritization of improvement ideas use effect-effort matrix as seen on Fig. 1.

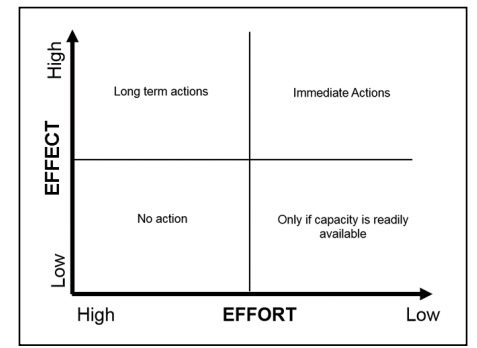

Fig. 1. Effect-Effort Matrix

Figure 1 helps to determine when the improvement idea will be carried out. If the effort needed is low with high effect, improvement idea should be carried out immediately. Improvements under category of high effort and effect are considered as long term actions. Improvements under category of low effort and effect can be done if the capacity is available. Some industrial problems have been solved using VSM. Saurin et al. [6] proposed framework to adopt lean practices in manufacturing cells using an automobile case. Chen et al.[7] attempted to improve the productivity using VSM and kaizen. Byfuglien et al improved Human Resource Management using Lean [8]. In addition, the application of Value stream mapping for administrative and office processes also have been done to eliminate office waste [9].

\section{RESULT AND ANALYSIS}

\section{A. Employee Contact Center}

Operational excellence is the department that acts as contact center for inquiries related to HR matters. There were about 3000 topics asked in contact center via both email and phone monthly. Data shows that there are various topics about HR matters that need response from generalists.

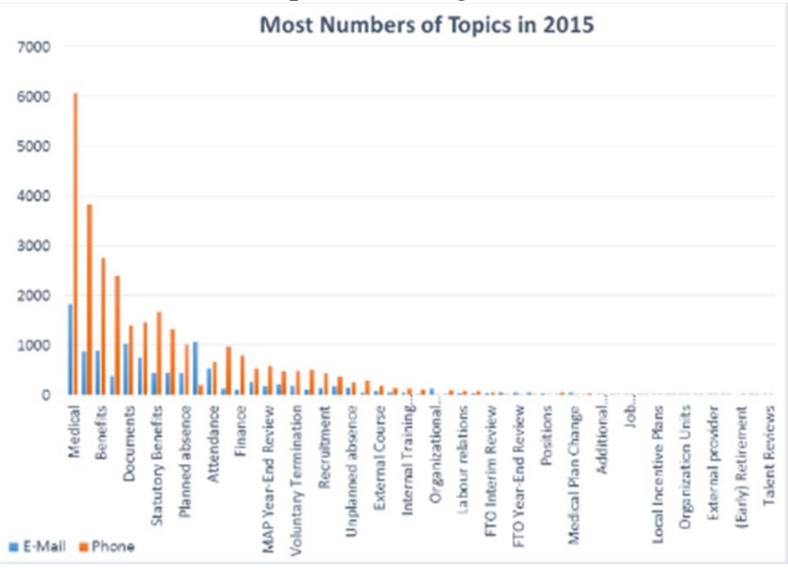

Fig. 2. Most Numbers of Topics Asked at Contact Center

It is shown in Fig. 2 that the most topic asked in the contact center is about medical. Based on generalist's information, the mostly asked medical subtopics were medical status and tick eligibility Medical Benefit Administration (MBA). These two subtopics were chosen to be mapped in VSM. SIPOC for medical status and MBA are shown in Table 1 and 2, respectively.

TABLE I. SIPOC Diagram FOR Medical Status

\begin{tabular}{|c|c|c|c|c|}
\hline (S)upplier & (I)nput & (P)rocess & (O)utput & (C)ustomer \\
\hline Employee & $\begin{array}{l}\text { Medical } \\
\text { Status } \\
\text { Inquiries }\end{array}$ & $\begin{array}{l}\text { Accept questions } \\
\text { about medical status }\end{array}$ & $\begin{array}{l}\text { Medical } \\
\text { status } \\
\text { informati } \\
\text { on }\end{array}$ & Employee \\
\hline \multirow[t]{2}{*}{$\begin{array}{l}\text { HR } \\
\text { Services } \\
\text { Indonesia }\end{array}$} & $\begin{array}{l}\text { Medical } \\
\text { Status } \\
\text { Records }\end{array}$ & $\begin{array}{l}\text { Find out about the } \\
\text { medical status by } \\
\text { coordination with } \\
\text { other department }\end{array}$ & \multirow[t]{2}{*}{$\begin{array}{l}\text { Ticket } \\
\text { data }\end{array}$} & $\begin{array}{c}\text { HR } \\
\text { Services } \\
\text { Indonesia } \\
\text { and HR } \\
\text { Shared } \\
\text { Services } \\
\text { Center } \\
\text { (SSC) Asia }\end{array}$ \\
\hline & & $\begin{array}{l}\text { Answer questions } \\
\text { about medical status } \\
\text { and close ticket }\end{array}$ & & \\
\hline
\end{tabular}

TABLE II. SIPOC DIAGRAM FOR ELIGIBILITY MBA

\begin{tabular}{|c|c|c|c|c|}
\hline (S)upplier & (I)nput & (P)rocess & (O)utput & (C)ustomer \\
\hline Employee & $\begin{array}{l}\text { Eligibility } \\
\text { MBA } \\
\text { Inquiries }\end{array}$ & $\begin{array}{ll}\text { Accept } & \text { questions } \\
\text { about } & \text { eligibility } \\
\text { MBA } & \end{array}$ & $\begin{array}{l}\text { Informati } \\
\text { on on } \\
\text { Eligibilit } \\
\text { y MBA }\end{array}$ & Employee \\
\hline \multirow[t]{2}{*}{$\begin{array}{l}\text { HR } \\
\text { Services } \\
\text { Indonesia }\end{array}$} & $\begin{array}{l}\text { MBA } \\
\text { status of } \\
\text { family } \\
\text { members }\end{array}$ & $\begin{array}{l}\text { Coordinate with } \\
\text { other department to } \\
\text { tick eligible MBA }\end{array}$ & $\begin{array}{l}\text { Ticket } \\
\text { Data }\end{array}$ & $\begin{array}{c}\text { HR } \\
\text { Services } \\
\text { Indonesia } \\
\text { and HR } \\
\text { Shared } \\
\text { Services } \\
\text { Center } \\
\text { (SSC) Asia }\end{array}$ \\
\hline & & $\begin{array}{lr}\text { Answer questions } \\
\text { about eligibility } \\
\text { MBA and close }\end{array}$ & & \\
\hline
\end{tabular}




\section{B. Talent Review}

Talent review (TR) is an annual process conducted by HR function of PT X. There are three important activities take place during talent review, namely 9-box calibration, career movement and succession. The processes from talent review which were chosen to be mapped were pre-post and the day of talent review. SIPOC diagram for talent review is shown in Table 3.

TABLE III. SIPOC DiAgram FOR TALENT REVIEW

\begin{tabular}{|c|c|c|c|c|}
\hline (S)upplier & (I)nput & (P)rocess & (O)utput & $\begin{array}{l}\text { (C)ust } \\
\text { omer }\end{array}$ \\
\hline $\begin{array}{l}\text { Head of } \\
\text { Function } \\
\text { and } \\
\text { Subfunction } \\
\text { of PT X }\end{array}$ & $\begin{array}{l}\text { Request on } \\
\text { succession } \\
\text { and career } \\
\text { movement for } \\
\text { positions and } \\
\text { employee } \\
\text { within } \\
\text { function }\end{array}$ & $\begin{array}{l}\text { Conduct } \\
\text { mini } \\
\text { talent } \\
\text { review } \\
\text { (subfunct } \\
\text { ion level) }\end{array}$ & $\begin{array}{l}\text { Talent review } \\
\text { results for } \\
\text { positions and } \\
\text { employees } \\
\text { within } \\
\text { function for } \\
\text { next } 3 \text { years. }\end{array}$ & $\begin{array}{l}\text { Head } \\
\text { of } \\
\text { Functio } \\
\mathrm{n} \text { and } \\
\text { Subfun } \\
\text { ction of } \\
\text { PT X }\end{array}$ \\
\hline $\begin{array}{l}\text { President } \\
\text { Director and } \\
\text { Regional } \\
\text { Head }\end{array}$ & $\begin{array}{l}\text { Request on } \\
\text { succession } \\
\text { and career } \\
\text { movement for } \\
\text { positions and } \\
\text { employee } \\
\text { within PT X }\end{array}$ & $\begin{array}{l}\text { Conduct } \\
\text { function } \\
\text { talent } \\
\text { review }\end{array}$ & $\begin{array}{l}\text { Talent review } \\
\text { results for } \\
\text { positions and } \\
\text { employees } \\
\text { within } \\
\text { company for } \\
\text { next } 3 \text { years }\end{array}$ & $\begin{array}{c}\text { Preside } \\
\text { nt } \\
\text { Directo } \\
\mathrm{r} \text { and } \\
\text { Region } \\
\text { al Head }\end{array}$ \\
\hline $\begin{array}{l}\text { Business } \\
\text { Partner (BP) } \\
\& \quad \text { HR } \\
\text { Services } \\
\text { Indonesia }\end{array}$ & $\begin{array}{l}\text { Previous } \\
\text { talent review } \\
\text { data }\end{array}$ & $\begin{array}{l}\text { Conduct } \\
\text { PT X } \\
\text { talent } \\
\text { review }\end{array}$ & & \\
\hline
\end{tabular}

\section{Employee Referral Program}

Employee referral program is conducted by talent acquisitions team. Every employee of PT X can participate to seek for the right candidates to fill the vacant positions. When the candidate successfully enters the company, the employee as referrer will receive certain amount of money as reward. This process were mapped into VSM. Detail SIPOC can be seen in Table 4.

TABLE IV. SIPOC DIAGRAM FOR EMPLOYEE REFERRAL PROGRAM

\begin{tabular}{|c|c|c|c|c|}
\hline (S)upplier & (I)nput & (P)rocess & (O)utput & (C)ustomer \\
\hline Referrer & $\begin{array}{l}\text { Candidate's } \\
\mathrm{CV} \text { and } \\
\text { consent } \\
\text { form }\end{array}$ & $\begin{array}{l}\text { Accept } \\
\text { referred } \\
\text { candidate's } \\
\mathrm{CV}\end{array}$ & Reward & Referrer \\
\hline \multirow[t]{2}{*}{ PT X } & $\begin{array}{l}\text { A need of } \\
\text { candidates } \\
\text { to fill } \\
\text { positions at } \\
\text { PT X }\end{array}$ & $\begin{array}{l}\text { Process } \\
\text { referred } \\
\text { candidate's } \\
\text { CV }\end{array}$ & $\begin{array}{l}\text { Accepted } \\
\text { candidate }\end{array}$ & PT X \\
\hline & & $\begin{array}{l}\text { Accept } \\
\text { referred } \\
\text { candidate } \\
\text { and reward } \\
\text { employee }\end{array}$ & & \\
\hline
\end{tabular}

\section{Employee Life Cycle Execution}

Employee life cycle execution is a process where employee goes through several job changes such as relocation, promotion, salary increase. This process is conducted by Complaints \& Benefits Services Team. As the process variation is huge, the manager brainstormed and decided on domestic relocation with promotion to be mapped. SIPOC for employee life cycle execution can be seen in Table 5 .

TABLE V. SIPOC DiAgRAM FOR EMPLOYEe LIFE CyCle EXECUTION (DOMESTIC RELOCATION WITH PROMOTION)

\begin{tabular}{lllll}
\hline (S)upplier & (I)nput & (P)rocess & (O)utput & (C)ustomer \\
\hline Manager & $\begin{array}{l}\text { Request } \\
\text { domestic } \\
\text { relocation } \\
\text { with } \\
\text { promotion }\end{array}$ & $\begin{array}{l}\text { Accept } \\
\text { Request }\end{array}$ & $\begin{array}{l}\text { Domestic } \\
\text { relocation } \\
\text { with } \\
\text { promotion } \\
\text { letter }\end{array}$ & Manager \\
HR & HR & $\begin{array}{l}\text { Execute the } \\
\text { life cycle }\end{array}$ & HR \\
Function & Database & $\begin{array}{l}\text { Hequested } \\
\text { Generate } \\
\text { PT X }\end{array}$ & $\begin{array}{l}\text { relocation } \\
\text { letter and } \\
\text { fulfill the } \\
\text { requirements }\end{array}$ & Function \\
& & & PT X \\
& & & \\
\end{tabular}

\section{E. Current State Value Stream Mapping}

After SIPOC diagrams were created, the four processes were then mapped into current state VSM can be seen in Fig. 3. The current flow of activities and time taken for each activity were described. The mapping was done together with manager, process doers, and customers.

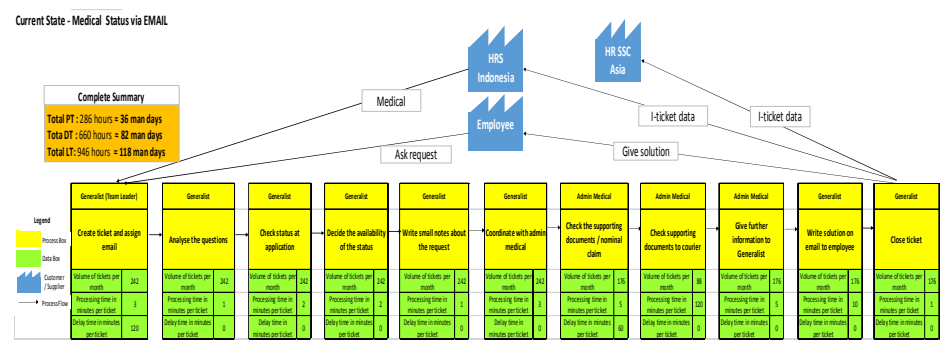

Fig. 3. Current state of Medical status via email

\section{F. Evaluation}

Waste, problems or issues identification process was carried out during current state mapping. The identification process was done in the following manners:

- Discuss each activity to identify waste or issues together with HR team in a meeting room.

- Observe certain process that was demonstrated by the process doer to identify waste or issues.

- Evaluation and improvements ideas on these processes have been agreed by HR team.

Several issues identified from medical status process are: 
- Employee waited for a long time for almost 2-3 hours for a reply thus it was suggested to reply immediately about medical status checking.

- There was a non-value added activity of making small note for coordination on paper so it was suggested to write on computer note and send to medical admin to minimize paper usage.

- There was waiting time for medical admin's response so there was a need for medical admin to allocate time to answer medical status inquiries from generalists.

- Hardcopy documents can result in inventory waste thus it was suggested to convert them to softcopy ones for the long-term plan.

- The most significant improvement that affects the efficiency of process was the information feature of documents completeness that can reduce volume of tickets. Two issues identified on eligibility MBA process are:

- There was one day waiting for global system to synchronize with local system for MBA status so it was suggested to provide information to all employees about it.

- There was waiting time around 3-4 minutes for the ticket to close.

The most significant improvement for process efficiency was the automatic tick eligibility MBA that can eliminate the question.

Several issues identified from talent review process are:

- There was long preparation time because of back and forth information between MOD and HR function (BP) so the suggestion was to set a mechanism standard.

- There was scattered data which caused HR Services Indonesia to consolidate data.

- Improvement suggestion was to create an integrated system to store and extract talent review data.

- The photo used during talent review was inappropriate.

- There was overproducing waste where people discussed unnecessary materials during talent review.

- MoM taker finds it difficult to record all information discussed as people talk together at once.

- The process took long time as there were many people to be discussed. The improvement idea was to plan for lower grade talent review to be conducted by managers themselves without HR facilitation.

- The three most significant improvement ideas for process efficiency were a creation of mechanism standard between MOD and BP, talent review discussion guideline and an integrated talent review tool.

Several issues identified from employee referral process are:

- There was back and forth between referrer and ERP admin about completing the ERP form so there was a need to provide practical guideline to complete ERP form.

- There was motion waste of checking whether candidate has been registered previously in application A.

- There were several manual activities which should be improved. An automatic "Thank You" email from ERP admin should be created.
- There were backlog issues of hold candidates. The suggested idea was to have weekly monitoring interview to solve it.

- There was delay time between processes which can be consolidated to reduce the delay time.

- There was transportation waste for sending documents from talent acquisition team to HR Services Indonesia.

- The most significant improvement ideas which affect process efficiency using low effort are collecting $\mathrm{CV}$ via email only, automated ERP database and email confirmation, and weekly monitoring interview to solve backlog issues.

Several issues identified from employee life cycle execution process are:

- Managers used wrong form and got confused so there was improvement idea to make macro-based guideline on how to use application $\mathrm{C}$.

- There was peer validation done by HR SSC Asia which was motion waste. The improvement was to delete the activity.

- There was waste motion where HR SSC Asia printed tickets so this activity was deleted.

- HR Services conducted audit on each transaction for internal control purpose.

- There was waiting time for letter to be generated. The improvement suggestion was to increase number of synchronization between local and global application from two to three times.

- There was manual work on updating number of home visits.

The most significant improvement ideas which affect process efficiency are number of synchronizations of two applications is increased, bundle validation and macro tool guideline for application $\mathrm{C}$. Each improvement idea was prioritized using effect-effort matrix. Action plan consists of level of effect and effort, duration, date of completion and name of person responsible.

\section{G. Future State VSM}

Future state VSM described the conditions of improved process within a period of one year. Suggested improvements are expected to improve on efficiency of processes, such as reducing volume of tickets, number of steps and time taken. Future state of medical status process is shown in Fig. 4.

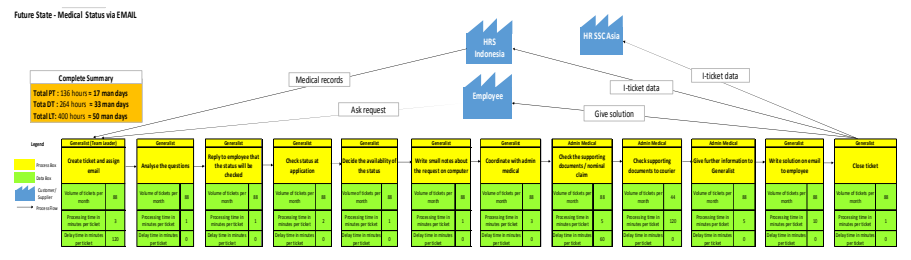

Fig. 4. Future State VSM of Medical Status

H. Savings

Improvement suggestions which emerged during the evaluation process were expected to improve HR processes. 
Process improvement was based on time efficiency obtained. Parameters used are processing time, delay time and lead time. Summary of time efficiency obtained by four processes can be seen on Table 6.

TABLE VI. SIPOC COMPARISON OF CURRENT AND FUtURE STATE VSM

\begin{tabular}{|c|c|c|c|}
\hline Parameter & Processing time & $\begin{array}{c}\text { Delay } \\
\text { Time }\end{array}$ & $\begin{array}{l}\text { Lead } \\
\text { Time }\end{array}$ \\
\hline \multicolumn{4}{|c|}{ Medical Status } \\
\hline Current (working days) & 36 & 82 & 118 \\
\hline Future (working days) & 17 & 33 & 50 \\
\hline Savings (working days) & 19 & 49 & 68 \\
\hline Savings (\%) & 53 & 60 & 58 \\
\hline \multicolumn{4}{|c|}{ Eligibility $M B A$} \\
\hline Current (working days) & 2 & 30 & 32 \\
\hline Future (working days) & 0 & 0 & 0 \\
\hline Savings (working days) & 2 & 30 & 32 \\
\hline Savings (\%) & 100 & 100 & 100 \\
\hline
\end{tabular}

TABLE VII. SIPOC COMPARISON OF CURRENT AND FUTURE STATE VSM (CONTINUED)

\begin{tabular}{|c|c|c|c|}
\hline Parameter & Processing time & $\begin{array}{c}\text { Delay } \\
\text { Time }\end{array}$ & $\begin{array}{l}\text { Lead } \\
\text { Time }\end{array}$ \\
\hline \multicolumn{4}{|c|}{ Talent Review } \\
\hline Current (working days) & 795 & - & - \\
\hline Future (working days) & 541 & - & - \\
\hline Savings (working days) & 254 & - & - \\
\hline Savings (\%) & 32 & - & - \\
\hline \multicolumn{4}{|c|}{ Employee Referral Program } \\
\hline Current (working days) & 2 & 51 & 53 \\
\hline Future (working days) & 1 & 41 & 42 \\
\hline Savings (working days) & 1 & 10 & 11 \\
\hline Savings (\%) & 50 & 20 & 21 \\
\hline \multicolumn{4}{|c|}{ Employee Life Cycle Execution } \\
\hline Current (working days) & 171 & 354 & 525 \\
\hline Future (working days) & 105 & 66 & 171 \\
\hline Savings (working days) & 66 & 288 & 354 \\
\hline Savings (\%) & 39 & 81 & 67 \\
\hline
\end{tabular}

Table 6 shows the savings of four processes in terms of processing time is more than $30 \%$. The savings in terms of delay time is more than $15 \%$. The savings in terms of lead time is more than $20 \%$. These savings benefit the company by speeding up the processes, reducing overtime, optimizing time for value added activities and satisfying the customers.

\section{CONCLUSION}

The four processes were employee contact center, talent review, employee referral program, and employee life cycle execution in HR analyzed with VSM. Contact centre process has high variation so medical status and eligibility MBA were the mapping scopes selected. Issue found was the question was asked by the employee because of long time taken to claim medical benefit. This was caused due to incomplete supporting documents needed. The improvement idea suggested was to add a feature of list of supporting documents needed when submitting the claim form. Eligibility MBA question was analyzed and found that there was a need to have an automatic tick system for eligible MBA. Talent review process is an annual process that involves many people and takes time. Waste identified was long preparation time because it was required to coordinate between $\mathrm{MOD}$ and $\mathrm{BP}$ as the facilitators and also motion to consolidate data. The improvement idea was to create standard for both stakeholders and also invent on a practical talent review tool which integrates 9-box, succession, movement and talent review result.

Employee referral process was analyzed and found that there was backlog issue of hold candidates. Employee life cycle execution process which was analyzed was domestic relocation with promotion. Waste identified was defect as manager used wrong form and got confused to fill at application $\mathrm{C}$. The improvement idea was to make a guideline on how to use application $\mathrm{C}$ in the form of macro-tool. Another waste found was overprocessing for validation so there was a need to reduce number of validations.

\section{REFERENCES}

[1] C. Barber \& B. Tietje,"A Research Agenda for Value Stream Mapping The Sales Process", Journal of Personal Selling \& Sales Management, Vol. 28 No. 2, pp. 155-165, 2008

[2] J. Byfuglien, H. Torstensen, \& A. Trolie, "The Improvement of HR Management by using Lean”, Norway Paper, pp. 1-7, 2012

[3] J.P. Womack, \& D.T. Jones, "Lean Thinking", 2nd Edition, New York: Simon and Schuster, 2010

[4] C. Barber \& B. Tietje,"A Research Agenda for Value Stream Mapping The Sales Process", Journal of Personal Selling \& Sales Management, Vol. 28 No. 2, pp. 155-165, 2008

[5] D.P. Lynch, "Enhancing the Effectiveness of Value Stream Mapping”, Quality Engineering Applications and Research, Paper 2014-2198, pp. 1-10, 2014

[6] T.A. Saurin, G.A. Marodin, and J.L.D. Ribeiro, “A framework for assessing the use of lean production practices in manufacturing cells", International Journal of Production Research, Vol. 48 No. 16, pp. 4215-30, 2010

[7] J. Chen, Y. Li, \& B. Shady, "From Value Stream Mapping Toward a Lean/Sigma Continuous Improvement Process: an Industrial Case Study", International Journal of Production Research. Vol. 48, No. 4, pp. 1069-1086, 2010

[8] J. Byfuglien, H. Torstensen, \& A. Trolie, "The Improvement of HR Management by using Lean”, Norway Paper, pp. 1-7, 2012

[9] B. Keyte, \& D.A. Locher, "The Complete Lean Enterprise: Value Stream Mapping for Administrative and Office Processes," New York: Productivity Press, 2004 